\title{
Assessing Climate Change in the Middle East from the Perspective changes in Air Temperature, Relative Humidity and Vector Wind: Land, Sea and atmosphere Interactions
}

Mohammad Jafar Nazemosadat ( $\nabla$ jafar@shrazu.ac.ir)

Shiraz University https://orcid.org/0000-0001-7753-9061

Afsaneh Heidari

Shiraz University Department of Water Engineering

\section{Sedighe Mehravar}

Shiraz University

\section{Research Article}

Keywords: Climate change, Middle East, Relative humidity, Air temperature, Wind, Nile, Euphrates and Tigris, Mediterranean Sea, Indian Ocean, Caspian Sea

Posted Date: March 1st, 2022

DOI: https://doi.org/10.21203/rs.3.rs-1330480/v1

License: (a) (1) This work is licensed under a Creative Commons Attribution 4.0 International License.

Read Full License 


\section{Abstract}

By utilizing summertime (June-September) gridded data of air temperature (AT), relative humidity (RH) and vector wind (VW), climate change was investigated over the whole of the Middle East (ME) and its ten sub-regions for the period of 1961-2020. Although changes were detected according to each individual variable, their interrelationships are discussed to justify the physical causes of the changes. For assessing the dynamic of climate change, stability in the changes was analyzed when significant results are compared between three choices comprising A) 19611990 and 1991-2020, B) 1961-1970 and 2011-2020 and C) 1961-1965 and 2016-2020. We proved that AT (westerly wind and RH) has (have) been predominantly increasing (decreasing) over the study area. The greatest (smallest) frequency of significant results was associated with choice $C(A)$ suggesting changes are on the rise. After proving that the Mediterranean Sea-based northwesterly winds are the main climate controller of the ME, a large part of the observed warming and dryness is attributed to the recent weakness in these circulations. The worrying changes were associated with some populous areas including upstream of the Nile River in Eritrea and Sudan and Euphrates and Tigers Rivers in Turkey, Caucasus regions, north of Egypt, north of Iran, Turkmenistan, Saudi-Arabia and Afghanistan. In contrast to the Mediterranean region, recent enhancements in the southerly (northerly) circulations over the Indian Ocean's northwest (Caspian Sea) have been partially compensated negative impacts of warming and dryness over some areas in Iran, Pakistan and the Arabian Peninsula (south of the Sea).

\section{Introduction}

The main motivation of the present study is to detect the signals of climate change over the Middle East (ME) and quantify the temporo-spatial measures of this change. Detection is the process of demonstrating that an observed change is significantly different from what can be explained by natural variability (Mitchell et al., 2001). However, in climate change analysis, detection does not necessarily imply that the causes of change are understood (Hansen et al., 1998; Schneider and Held, 2001; van Loon and Shea, 2000; Wigley et al., 2000).

Although analyses of the air temperature (AT) time series are the popular approaches for detecting climate change, we analyzed concurrent variations in air temperature, relative humidity (RH) and vector wind (VW) to uncover their inter-relationships in more detail. According to the World Bank's report climate change will cause extreme heat to spread across more of the land for longer periods of time, making some of the Middle Eastern regions unlivable and reducing growing areas for agriculture (https://www.worldbank.org/en/programs/mena-climate-change).

In terms of climate change, the ME and North Africa are the most vulnerable areas in the world (Karl et al., 1996; Sowers et al., 2011; Wodon et al., 2014). These areas with an ever-increasing rate of population are classified as the driest and waterless parts of the world (Ashton, 2002). Due to such climate features, success in economical and particularly agricultural activities highly depends on the characteristics of precipitation variability on a regional scale. In the Middle East, the limited water resources are widely 
shared by countries with enormous differences from economic, political, and military points of view. These discrepancies are intensified by climate change so that access to water supplies and delivery systems might be considered as the military targets (Gleick, 1994). A positive trend in the air temperature over some parts of the ME have been reported by a few investigators (Efthymiadis et al., 2011; Kuglitsch et al., 2010; Lelieveld et al., 2012; Maheras et al., 2006; Tanarhte et al., 2012).

According to the results of 18 global climate models, it is anticipated that overall temperature increase over the ME is around $1.4 \mathrm{C}$ by mid-century, increasing to almost $4^{\circ} \mathrm{C}$ by late-century. Moreover, a decrease in precipitation is also predicted for Turkey, Syria, Northern Iraq, Northeastern Iran, and the Caucasus region (Evans, 2009). Considering the adverse consequences of climate change, some investigators have been worried about the future of living conditions in the ME and North Africa during the 21st century (Thompson and Zakhirova, 2021).

It has been recently reported that conditions in the Persian Gulf region, including its shallow water and intense sun, make it "a specific regional hotspot where climate change, in absence of significant mitigation, is likely to severely impact human habitability in the future" (Pal and Eltahir, 2016). According to their findings, weather conditions in many major cities such as Doha-Qatar, Abu Dhabi, and Dubai in the United Arab Emirates, Kuwait as well as Bandar Abbas and Mahshahr in Iran could exceed a tipping point for human survival, even in shaded and well-ventilated spaces. The combinations of high temperature and relative humidity reduce the life expectancy and community resilience critically. The results of new studies infer that the events that now occur once every 20 years or so "will characterize the usual summer day in the future" (Pal and Eltahir, 2016). In some parts of the Saudi Arabia the concurrent increase of air temperature and relative humidity deteriorates the general health condition and upsurges the incidence of deadly heat shocks (Petkova et al., 2015). It has been reported that the average local temperature in Jordan has increased at very rapid rate since 1990 and temperature rise during five decades is about $1.5-2.0^{\circ} \mathrm{C}$ (Matouq, 2008).

The negative or positive effects of climate change on the agricultural activities mostly depend on the geographical characteristics of the farmlands (Alam et al., 2016; Alexander et al., 2006; Amarnath and Mishra, 2017). While, global warming mostly facilitates these activities over the frozen areas in Canada and Siberia an ever-increasing demand of water is the main consequence of global warming in tropical and Mid-latitude regions. In most developing countries which are generally located over the low latitude areas, destructive effects of climate change on agriculture is much more highlighted than those countries situated over the high latitudes regions (Boonwichai et al., 2019). Agricultural activities are highly dependent on the status of air temperature and humidity, and significant change in these parameters escalates abnormality to these activities (Alexander et al., 2006). For example, rice production and food security at the low latitude areas of Asia are at risk if air temperature is critically increased (Alam et al., 2016; Gentle and Maraseni, 2012; Maraseni et al., 2018; Yoshida et al., 2015).

For the near-surface atmospheric layers, one degree increase (decrease) in air temperature improves (declines), the holding capacity of atmospheric water by about \%7 (Trenberth and Fasullo, 2009; 
Wyszyński and Przybylak, 2014). Therefore, global warming can potentially intensify the volumes of flash flood and increase the occurrence probability of devastating storms in various parts of the world (Gunawardhana et al., 2017; Nazemosadat et al., 2016). As an example, the increased flood events in the southern parts of England are attributed to the anthropogenic part of the global warming (Schaller et al., 2016).

It has been reported that in addition to the average air temperature, the frequency of extreme warming events in the ME and North Africa has also been increasing since the 1970s (Tanarhte et al., 2015; Zhang et al., 2005). More than $90 \%$ of the station data processed in Saudi Arabia showed an increasing trend in the daytime and nighttime air temperatures (Almazroui et al., 2014). Nazemosadat et al. (2016) have been projected the measure of the changes in air temperature and precipitation in Iran for the 2040-2050. Shirvani et al. (2015) have found significant change in the Persian Gulf's sea surface temperature (PGSST). The El Niño-Southern Oscillation (ENSO) has been introduced as an influential external forcing for climate change in Iran (Nazemosadat et al., 2006).

If enough moisture is available, air can hold water molecules until it reaches to the saturated vapor pressure. However, in most inland areas, the air is not saturated and the actual vapor pressure is less than the saturated condition. The ratio of actual vapor pressure to the saturated vapor pressure is called relative humidity and expressed as the percentage values (Nazemosadat and Ghaedamini, 2010). In Polar Regions and equatorial maritime air is saturated and the relative humidity is predominantly $\% 100$. On the other hand, for the mid-latitude areas such as the ME, relative humidity is the lowest value on the global scale. Relative humidity is in strong connection with hydrological cycle (precipitation, aggregation and evaporation), surface energy balance and climate change (Choy et al., 2015; Ross and Elliott, 1996). A negative trend was detected in the time series of relative humidity in various parts of Iran and particularly in the central and eastern regions (Noshadi and Ahani, 2015). According to their report, air temperature and relative humidity were negatively correlated over most of these regions. We could not find documents that analyzed climate change over the ME from the perspective of relative humidity.

In addition to air temperature and relative humidity, assessing changes in the wind data (U-wind and Vwind) is also the other goal of this study. Vector-wind represents wind speed in the horizontal and meridional directions and the inflow angle. Wind plays an influential role in the global water and energy balance by transferring water needed for the formation of clouds and precipitation production (Trenberth and Fasullo, 2009). Those winds that are blowing from the marine environments into inland areas (from landmasses into marine areas) generally increase (decrease) the humidity. Relative humidity generally increases (decreases) when winds blows poleward (equatorial-ward) or from lowland into mountainous (highland into lowland) areas. The authors did not find researches that assess climate change in the ME from the perspective of changes in the wind data. Furthermore, the interaction between changes in AT, RH and wind data has not yet been investigated over the study area. The influence of the main water bodies such as the Mediterranean Sea, Black Sea and the western parts of the Indian Ocean on climate change over the ME has also not been well documented. 
Since water scarcity and severity of heat waves are serious during the hot months of the year, we utilized our own methodology to detect the spatio-temporal changes in the summertime data of these variables over the last sixty years period (1961-2020). In addition to the whole of the Middle East, the analyses were also performed over ten populous sub-regions of this geographical domain. For assessing the dynamics of climate change, comparison was made between successive and discrete periods having various record lengths. The study has also assessed the influence of the atmospheric circulation on the change in the AT and RH data. These influences will particularly be evaluated for the Mediterranean Sea, northwestern areas of the Indian Ocean, Caspian Sea and the upstream of some important rivers.

\section{Data And Methods}

Mean values of the summertime (June-September) surface air temperature (AT), relative humidity $(\mathrm{RH})$ and the $700 \mathrm{~h}-\mathrm{Pa}$ vector wind over the ME (Figure 1) are gratefully extracted from the NOAA webpage for all $2.5^{\circ} \times 2.5^{\circ}$ pixels (https://psl.noaa.gov/cgi-bin/data/composites/printpage.pl). At the first stage, the extracted data comprised two sets of the mean values of these variables that were associated with two consecutive 30 years periods (1961 to 1990 and 1991 to 2020). Therefore, for each of these three variables, two digits are assigned to each pixel. While the first digit shows the mean seasonal value for 1961 to 1990, the second one is the corresponding value for 1991 to 2020 (Figures 1 and 2). While Figure 1 depicts spatial distributions of the mean values of AT, RH and VW for 1961-1990, Figure 2 shows these values for 1991-2020.

The non-parametric Kolmogorov-Smirnov (K-S) field significant test (Marsaglia et al., 2003) is used to examine if the distribution functions of the data of all pixels spread over various parts of the ME (315 Pixels in total) are different (at $95 \%$ or $90 \%$ level, herein depicted as * or **, respectively) between Figures 1 and 2 (choice A). In addition to this test, differences are also assessed by using the parametric t-test as indicated by (Baldi and Long, 2001). Since the results are generally found similar, the presented statistics are only related to the K-S test. The significant changes in the AT, RH or vector wind [(zonal (UW) and meridional (VW)] data were considered as the signal of climate change from the perspective of that particular variable.

For evaluating climate change in more detail and assessing the dynamics of climate change, the abovementioned procedures were repeated to examine differences in the variables between the first and last decades of the study period (1961-1970 and 2011-2020; choice B). In the last stage, the changes are detected between the first and last five years periods (1961-1965 and 2016-2020; choice C). In addition to the whole of $\mathrm{ME}$, the mentioned climate change detection was also performed for ten sub-regions of this geographical expanse as indicated in Figure 4 and Table 1. The selection of sub-regions was found to be beneficial for better demonstration of climate changes over some specific regions for which changes seem to be considerable for one or more variable.

\section{Results And Discussion}




\section{1- General features of AT, RH and VW (1961-1990 and 1991-2020)}

Figure 1 shows the mean values of summertime air temperature (AT; contour lines), relative humidity (RH; shadings) and vector wind (VW; arrows) for the period of 1961-1990. The highest values of seasonal air temperature (greater than $30^{\circ} \mathrm{C}$ ) are seen over more populous parts of the study area including Iran, Saudi Arabia, Iraq, Kuwait, United Arab Emirate, Bahrain, Qatar, Sudan, Egypt, Turkmenistan and Afghanistan. These areas that mostly locate between the subtropical-high pressure belt $\left(25^{\circ}-35^{\circ} \mathrm{N}\right)$, can be characterized as the region with the highest values of AT and lowest amounts of $\mathrm{RH}$ (contour lines and yellow shading in Figure 1, respectively). For most parts of the study area, maximum values of $\mathrm{RH}$ are harmonized with low amounts of air temperature. However, the low values of AT and the near saturation humidity are dominant in some high latitude areas of ME such as the western coasts of the Black Sea in Georgia and northeast of Turkey. For the marine environments and coastal areas, regardless of air temperature, $\mathrm{RH}$ is generally near $100 \%$ (Figure 1 ).

According to Figure 1, southern parts of Europe and the Mediterranean Sea are the main sources of airflows that blow over the ME and North Africa. These northwesterly airflows could be considered as the foremost respiratory system or nose of these geographical expanses. If the ME is considered as a room, its fresh air is supplied by these northwesterly circulations. In their over-sea travel, these westerly winds are divided into two distinct parts, namely southern and northern flanks. While the southern flank transfers (drain) moisture into the northern parts of Egypt, Libya and Saudi Arabia (the southern coasts of Turkey), the northern flank propagates eastward or northeastward. The southern airflow becomes warmer and dryer as travel toward the lower latitudes of Africa and Saudi Arabia. As indicated in Figure 1, the main parts of Sudan are the ultimate destination of the warm and dry air-flows that are passed over Egypt and Saudi Arabia.

Although blowing the southern flank enhances humidity over North Africa and Saudi Arabia, this enhancement is highlighted only over the southern coasts of the Mediterranean Sea (blue shadings in southern parts of the Sea in Figure 1). Compared to coastal regions of Egypt and Libya, the magnitudes of RH are less in Turkey's southern coasts; where wind has the land to Sea direction.

Those geographical expanses that are affected by the northerly flank include some areas in Syria, Jordan, Iraq, north of Iran, the Caspian Sea, Azerbaijan, Armenian, Georgia, Turkmenistan, the eastern half of Iran and western half of Afghanistan. In contrast to the southerly flank which is generally blowing southward, the direction of northerly flank changes to southwesterly or southerly over some areas including east of Turkey, northwest of Iran, the Caspian Sea, Azerbaijan, Georgia and Armenia (Figure 1). This northward circulation generally increases $\mathrm{RH}$ and decrease AT over its passages.

As is indicated in Figure 1, a part of the Caspian Sea-based southerly wind changes its direction toward Turkmenistan to blows as the westerly wind. These westerly airflows turn into the northerly wind in the middle of the road to enter Iran and Afghanistan (Figure 1). While a part of this northerly circulation reaches the Indian Ocean in southeastern parts of Iran, the other part blows toward tropical areas of 
Africa via the Persian Gulf, Oman Sea and the Arabian Peninsula. Therefore, the Oman Sea in the northwestern parts of the Indian Ocean and tropical parts of North Africa are the ultimate destinations of the northern flank of the Mediterranean-based circulations (Figure 1).

The magnitudes of AT and RH are mostly modulated by the velocity and direction of the mentioned atmospheric circulations. For instance, for eastern half of Iran, the magnitude of these variables depends on the strength of northerly winds that come from Turkmenistan. Moreover, the amount of these variables over Eritrea and Sudan are mostly controlled by the characteristics of the warm and dry winds that come from Saudi Arabia.

Figure 2 is similar to Figure 1 except that the former is related to the period of 1991 to 2020 . Although the geographical distributions of AT, RH and VW are similar in these two Figures, the magnitudes of AT (RH) have predominantly increased (decreased) during the second 30 years period. For instance, for some areas such as western parts of Afghanistan and Pakistan, decrease in relative humidity is obvious for the second period. The easterly and northerly (westerly and southerly) winds are also generally stronger for the second (first) 30 years period.

\section{2- Differential values}

For demonstrating the signals of climate change more clearly, differential values between Figures 1 and 2 are depicted in Figure 3.The positive (negative) values of isotherms imply that weather is warmer (colder) during 1991-2020 as compared to its earlier period (1961-1990). Since all the isotherm's labels are either positive or zero, it can be concluded that warming is the dominant feature of the Middle Eastern climate (contour lines in Figure 3). According to the presented statistics in Table 1 (first line), compared to the first 30 years period, for the whole of Middle East, AT (RH) has been warmed up (dried) by $0.83^{\circ \mathrm{C}}(1.93 \%)$ in the second period. The highest values of warming associate with some areas including northeastern parts of Iran and their nearby areas in Afghanistan and Turkmenistan, the south Cuscuses regions, western areas of Saudi Arabia along the Red Sea, the central parts of Turkey, north part of Egypt, south of Sudan and eastern parts of Eritrea (Table 1).

Except for a small area of ME that is denoted as blue shading in Figure 3, RH is either unchanged or decreased over the other areas. The magnitudes of this decrease vary from about $1 \%$ in central south of Iran to around $10 \%$ in some parts of Sudan and Eritrea; almost along the latitude $15^{\circ} \mathrm{N}$. The decrease (increase) in RH (AT) is also remarkable in the high latitude areas of the ME such as the northwestern and northeastern districts of Iran, most of Caucasus region and the eastern parts of Turkey (Figure 3 and Table 1). The regions with increase in the $\mathrm{RH}$ data include a small area in the southeast of Iran, total territory of Oman, northern parts of Yemen, southwestern coasts of Pakistan, Cyprus and a part of Turkey's southern coasts. Climate change is also particularly investigated over a part of Oman (region $\mathrm{H}$ in Figure 4).

For the central and northeastern parts of Iran; where temperature rise is one of the highest in the Middle East, the moisturized westerly (dry easterly) winds during the recent period are weaker (stronger) than that 
of the first period (Figure 3). Similarly, compared to the period of 1961-1990, blowing the dry northerly winds is generally stronger over Turkmenistan and the northeastern parts of Iran for the recent 30 years. These southward wind increases air temperature over the northeastern parts of Iran and central districts of Turkmenistan. Also, the observed temperature rise in the western parts of Saudi Arabia and Cuscuses region mostly associates with the strength in the dry northerly winds over these areas during the recent period. Comparing Figures 1, 2 and 3 implies that the southerly winds over the Caspian Sea are decreasing. This reduction partially justifies the observed decrease in the $\mathrm{RH}$ data over the neighboring countries such as Turkmenistan and Azerbaijan.

In contrast to other regions, for southeastern corner of the ME that includes Oman, the northern parts of Yemen and southeastern extremity of Iran, the northerly winds have been recently either weakened or replaced by the moisturized southerly and easterly winds that lessen the adverse consequences of climate change over these regions (blue color in Figure 3 and region $\mathrm{H}$ in Table 1). However, the situation is slightly different for Cyprus and southeastern coasts of Turkey for which a marginal-improvement in the $\mathrm{RH}$ data coincides with a considerable increase in the AT. This improvement is mostly due to the recent weakness (strength) in the northerly (southerly) winds.

The suppressed northerly and westerly wind over the Mediterranean Sea decreases cold advection from the high latitude areas of Europe and the Atlantic Ocean into the ME during recent periods. This suppression increases (decreases) AT $(\mathrm{RH})$ over this area by reducing the volume of the circulated air.

Table 2 summarizes the results of the Kolmogorov-Smirnov (K-S) test that were conducted to assess significant changes in AT, RH, UW, and VW between the first and second 30-year periods. Besides the whole of ME, the results are also shown for ten sub-regions of this expanse. According to the given statistics, in addition to the whole of $\mathrm{ME}$, increase in air temperature is also significant for the sub-regions $\mathrm{B}, \mathrm{E}$ and $\mathrm{J}$. Although decrease in $\mathrm{RH}$ is almost overwhelming, it is only significant for region $\mathrm{B}$ and $\mathrm{c}$. The significant change in wind data associates with Turkey, west of Turkey, north of Egypt and the East Mediterranean Sea (regions F, G, I and J, respectively). For these areas, northward (southward) component of the vector wind is enhanced (suppressed) during the recent 30 years period. These changes lead to the improvement (suppression) of wetness over southwestern parts of Turkey (northern parts of Egypt and eastern parts of the Mediterranean Sea).

\section{3- Decadal analysis}

Figures 5, 6 and 7 are, correspondingly, similar to Figures 1, 2 and 3 except those three formers are related to the first and last decades of the study period; namely 1961-1970 and 2011-2020. In other words, instead of two consecutive 30-year periods, the data are analyzed for two discrete decades. Comparison between Figures 3 and 7 and Tables 2 and 3 implies that differences are more significant if instead of 30 years, changes are evaluated between the first and last decades. For instance, while maximum difference in AT data over the Iran-Turkmenistan regions is about $1.5^{\circ} \mathrm{C}$ in Figure 3 , it varies between $2.0^{\circ} \mathrm{C}$ and $3.0^{\circ} \mathrm{C}$ in Figure 7. Similarly, for Sudan, air temperature in Figure 7 is nearly twice of that in Figure 3. For some 
parts of Sudan and Eritrea that locate around $15^{\circ} \mathrm{N}$, AT has increased from $3^{\circ \mathrm{C}}$ to $4.0^{\circ \mathrm{C}}$ which is the highest value over the study area. Consistent with the increase in AT, decrease in RH data is more evident in Figure 7 as compared to Figure 3. Tropical parts of Africa, east of Turkey, Azerbaijan, most of Afghanistan and northern parts of Egypt are the areas that are subjected to the greatest decrease in RH (Figure 7). The decrease is acute for the mentioned areas in Sudan and Eritrea; where the RH reduction reaches to about $27 \%$. These areas are upstream of the Nile River; the main water resources of Egypt. Unfortunately, the second sharpest decrease in RH data lies over the central and eastern parts of Turkey; where the Euphrates and Tigris Rivers are originated. The mountainous area in the western and northwestern parts of Iran that is the origin of Iran's main rivers have also been subjected to about $1.5^{\circ \mathrm{C}}$ to $2.0^{\circ \mathrm{C}}$ increase in $\mathrm{AT}$ and up to $5 \%$ decrease in the $\mathrm{RH}$ data.

Comparing Figures 3 and 7 and the presented statistics in Table 1 to 3 suggest that, compared to some areas such as Sudan or east of Turkey, Iran's relative humidity particularly over its eastern half tends to be stable. This stability could mostly be attributed to the pouring of the Indian Ocean moisture into Iran via the northeastern districts. Besides eastern districts, a white patch in the southeastern coasts of the Caspian Sea (Figure 7) implies that, due to the recent enhancement in the over-sea northerly winds, $\mathrm{RH}$ data have also slightly improved over this region. Noshadi and Ahani (2015) have also reported a positive trend in the RH data of this area. The presented statistics in Table 3 imply that for some areas such as west of Turkey, north of Egypt, east of the Mediterranean Sea, Oman (Azerbaijan, Armenia, the Caspian Sea, the central parts of Turkmenistan, most of Iran, Afghanistan, Saudi Arabia and Sudan). The northward (southward) component of the vector-wind has recently enhanced.

Comparison between Figures 3 and 7 and the provided statistics in Tables 1 to 3 supports our previous discussion about improvement or stability in the RH or AT data over Oman, some parts of Yemen, southwestern coasts of Pakistan and the southeastern corner of Iran, respectively. While air temperature over these areas has increased from 0.5 to $1.0^{\circ} \mathrm{C}$ during the last six decades, $\mathrm{RH}$ data are improving over time. This improvement is mostly associates with the enhanced southeasterly wind over the northwestern parts of the Indian Ocean which improves the natural ventilation system of the ME. In the other words, the enhanced southeasterly winds over this part of the Indian Ocean have been marginally compensated the adverse effects of the suppressed northwesterly winds over the Mediterranean Sea. These findings are consistent with one of the latest IPCC's reports that anticipates increase precipitation over land in most of East Asia at the end of the 21st century due to the strengthened summer monsoon circulation (IPCC 2021). For Cyprus and the southeastern coasts of Turkey AT or RH has increased by about $2.5^{\circ \mathrm{C}}$ or $4 \%$, respectively.

The increase in the $\mathrm{RH}$ data is mostly due to the recent amplification (weakness) in the southerly and easterly (northerly and westerly) winds over the Mediterranean Sea (Figure 7). As is discussed earlier, the weakening of northwesterly winds over the Mediterranean Sea straitens the respiratory system of the ME and increases its warming. Northward component of the vector-wind has also strengthened in west of Turkey and north of Egypt. 


\section{4- 5 years analysis}

For consolidating the obtained results, significant differences in the considered variables were investigated between the first and last five years of the study period (1961-1965 and 2016-2020). The spatial distribution of AT, RH and WV (not shown) were mostly found to be similar to those shown in Figures 5 and 6. Figure 8 and Table 4 are, correspondingly, similar to Figure 7 and Table 3 except those formers are related to these two five years analyses. The number of significant results in Table 4 as well as differential values in Figure 8 are greater than corresponding values in Table 3 and Figure 7, respectively. For example, the given information in Figure 8 suggests that, for some parts of Sudan and western sides of Eritrea, the difference in AT (RH) escalates to $5.0^{\circ} \mathrm{C}(30 \%)$ which are greater than the corresponding values in Figures 3 or 8 . These two statistics are, respectively, about $2.5^{\circ} \mathrm{C}$ and $13 \%$ for the middle and eastern parts of Turkey; where the Euphrates and Tigris Rives are originated (Figure 8 and Table 4). Meanwhile, the increase (decrease) in AT (RH) data for the Caucasus region and northwestern parts of Iran varies from $1.5^{\circ} \mathrm{C}$ in south to $3^{\circ} \mathrm{C}$ in the north (5\% to $\left.13 \%\right)$. Besides these, differences values in the AT data are worrying over some areas including northern parts of Egypt $\left(3.0^{\circ} \mathrm{C}\right)$, the middle parts of Turkmenistan, $\left(3.0^{\circ} \mathrm{C}\right)$ western side of Saudi Arabia $\left(2.5^{\circ} \mathrm{C}\right)$ and northeastern parts of Iran $\left(2.5^{\circ} \mathrm{C}\right)$.

For some areas mostly situated in the southeastern parts of the ME, differential values in the AT (RH) data have been almost stabilized (increased) over time. For instance, increase in temperature (RH) data of Oman, north of Yemen and the southeastern coasts of Iran varies from zero to about $0.5^{\circ \mathrm{C}}$ ( $2 \%$ to $8 \%$ ). Although difference in the AT data suggests a considerable warming over some areas including United Arab Emirate, Qatar, the eastern parts of Saudi Arabia and central south of Iran, RH data exhibit a marginal improvement over these areas. This improvement could be mostly attributed to the the enhanced southerly wind over these parts of the ME.

A comparison between Figures 3, 7 and 8 suggests that, for most parts of Iran, $\mathrm{RH}$ data are improving during the recent decade. For instance, the areas that are shown by white color (yellow color) in Figure 3 have been substantially increased (decreased) in Figures 7 and 8 suggesting that $\mathrm{RH}$ is improving over the country. Besides this, the regions with a sharp reduction in the RH data are getting distance from Iran's territory. As an example, according to the given information in Figure 3, the northwestern parts of Iran and most of the Caucasus region, have experienced a sharp reduction in the $\mathrm{RH}$ data during the recent 30-year periods (brown and yellow colors in Figure 3 for the latitudes above $35^{\circ} \mathrm{N}$ ). However, as indicated in Figures 7 and 8 , the areas with such characteristics have been gradually moved toward the west or north, to be centered over eastern and central parts of Turkey or northern parts of the Caucasus region.

The increase in RH data over a considerable part of Iran and the Arabian Peninsula could mostly be attributed to the strengthened southeasterly and easterly circulations over the northwestern parts of the Indian Ocean which stabilize AT and increase RH over these parts of the ME. Overall, weakness in the northwesterly winds over the Mediterranean Sea is partially compensated by the strengthened southeasterly airflows over the northwestern parts of the Indian Ocean. Furthermore, climate condition in the northern parts of Iran is also influenced by the atmospheric circulation above the Caspian Sea. As an 
example, compared to Figures 3 and 7, Figure 8 shows less difference in the air temperature and humidity over the southern parts of the Sea. Therefore, for this part of Iran, the magnitudes of AT and RH during 2016-2020 are similar to the corresponding values during 1961-1965. This stability in climate condition is partially due to the recent weakness (strength) in the southerly (northerly) winds over the Caspian Sea.

Comparison between Figures 3, 7 and 8 infers that, for most parts of the Black Sea, Turkey and the East Mediterranean Sea, the westerly and northerly (easterly and southerly) winds have been recently weakened (enhanced). Moreover, wind direction over the eastern coasts of the Black Sea is mostly northwesterly or (westerly) during the first (resent) periods, respectively. This means that moisture transport from the Black Sea into Turkey is decreasing. Blowing the dry southeasterly winds over Turkey are increasing. These winds that come from northern parts of Iraq and Syria induce dryness over central to eastern parts of this country. Although, moisture transport has been increased from the Mediterranean Sea into the southern coasts of Turkey with, RH data are decreasing over most parts of the country and particularly its eastern half.

\section{Conclusion}

We examined climate change over the ME by detecting significant difference in the mean values of summertime (June-September) surface air temperature (AT), relative humidity (RH), and the $700 \mathrm{~h}-\mathrm{Pa}$ vector wind. The examination was firstly conducted between two succeeding 30-year periods; namely 1961-1990 and 1991-2020 (choice A). In addition to these two successive 30-year periods, changes are also detected between the first and last decades of the study period (19611970 and 2011-2020; choice B) as well as between the first and last five years of this sixty years period (1961-1965 and 2016-2020; choice $\mathrm{C}$ ). Besides whole of the ME climate change was also assessed over ten sub-regions of this geographical expanse.

By analyzing the main routes of atmospheric circulation over the $\mathrm{ME}$, we have shown that the northwesterly airflows over the Mediterranean Sea are the main climate controller and fresh-air's supplier of this geographical expanse. While the northern flank of this circulation plays an influential role for controlling AT and RH over the areas mostly located in the eastern and northeastern parts of the Sea, climate condition in the southern and southeastern sides of the Sea is mostly controlled by the southern flank. The increased (decreased) in the AT (RH) data over various parts of the ME is remarkably influenced by the recent weakness in these northwesterly airflows. Moreover, the observed decline in the $\mathrm{RH}$ data over the Caucuses region and Turkmenistan was partially attributed to the suppressed southerly winds over the Caspian Sea. We have discussed how changes in the wind direction modulate change in the AT and RH data over Egypt, Cyprus and Turkey. Change in the direction of atmospheric circulation over various parts of the ME was also considered as an influential parameter for justifying the observed fluctuations in the AT and RH data.

While the choice $B$ is in the Middle, air temperature warming (decrease in relative humidity) for choice $C$ was generally greater than choice $\mathrm{A}$. The most worrying warming and decrease in $\mathrm{RH}$ data are related to 
the upstream of Nile River in Eritrea and Sudan, Euphrates and Tigris Rivers in Turkey as well as the rivers that flow in Caucasus region and northwestern parts of Iran. Moreover, raising air temperature and declining humidity are distressing for some areas such as most of Syria, Iraq, Turkmenistan, Afghanistan, northern and western parts of Saudi Arabia and northeastern parts of Iran.

For the upstream of the Nile River in south of Sudan and the eastern part of Eritrea the warming ( $\mathrm{RH}$ reduction) had been reached to about $1.6^{\circ} \mathrm{C}, 3.5^{\circ} \mathrm{C}$ and $5.5^{\circ} \mathrm{C}(12 \%, 27 \%$ and 30$)$ for the choices $\mathrm{A}$, $\mathrm{B}$ and $\mathrm{C}$, respectively. The corresponding values for the Caucasus region and northwestern parts of Iran are about $1.2^{\circ} \mathrm{C}, 2.5^{\circ} \mathrm{C}$ and $3^{\circ} \mathrm{C}(6 \%, 9 \%$ and $10 \%)$. These values change into $1.2^{\circ} \mathrm{C}, 2.0^{\circ} \mathrm{C}$ and $2.5^{\circ} \mathrm{C}(6 \%, 11 \%$ and $14 \%$ ) for the central and eastern parts of Turkey. The intensification of the observed changes from option A to option C implies an ever increasing (decreasing) in AT (RH) data for most of the ME.

In contrast to the other parts of the ME, the enhanced southerly and easterly winds over the northeastern parts of the Indian Ocean have improved humidity the adjacent landmasses in Oman, northern parts of Yemen and the southeastern corner of Iran. Besides increasing $\mathrm{RH}$, pouring the moisturized air has also stabilized air temperature over these areas. In other words, the negative consequences of the suppression in the northwesterly circulation over the Mediterranean Sea are partially compensated by improvement in the southeasterly circulation over the northwestern parts of the Indian Ocean. The recent enhancement (suppression) in the northerly (southerly) wind over the Caspian Sea plays an influential role for improving $\mathrm{RH}$ and stabilizing AT over the southern parts of the Sea in Iran.

\section{Declarations}

\section{Ethical Approval}

Hereby, we consciously assure that the manuscript:

\section{Assessing Climate Change in the Middle East from the Perspective changes in Air Temperature, Relative Humidity and Vector Wind: Land, Sea and atmosphere Interactions}

is the authors' own original work, which has not been previously published or considered for publication elsewhere.

\section{Author Contributions}

All authors contributed to the conception and design of the study as indicated in the order of authors.

Under the supervision of the first author, the first draft of the manuscript was written by the second author as a students' research work. The findings have then been improved by the authors from the scientific and writing points of view. All authors have read and approved the final manuscript.

\section{Consent to Participate}


We voluntary participated in this research project which has not been funded by the governmental or private agencies.

\section{Consent to Publish}

The undersigned authors give our consent for the publication of identifiable details, which can include photograph(s) and/or videos and/or case history and/or details within the text ("Material") to be published in the above Journal and Article. Therefore, anyone can read material published in the Journal.

\section{Funding}

The authors declare that no funds, grants, or other support were received during the preparation of this manuscript.

\section{Competing Interests}

The authors have no relevant financial or non-financial interests to disclose.

\section{Availability of data and materials}

The datasets generated during and/or analysed during the current study are available from the corresponding author upon reasonable request

\section{References}

1. Alam MK, Ahmed S, Anjum S, Akram M, Shah SMA, Wariss HM, Hasan MM, Usmanghani K (2016) Evaluation of antipyretic activity of some medicinal plants from Cholistan desert Pakistan. Pak J Pharm Sci 29:529-533

2. Alexander LV, Zhang X, Peterson TC, Caesar J, Gleason B, Klein Tank A, Haylock M, Collins D, Trewin $B$, Rahimzadeh $F$ (2006) Global observed changes in daily climate extremes of temperature and precipitation. J Geophys Research: Atmos 111. doi:10.1029/2005JD006290

3. Almazroui M, Islam MN, Dambul R, Jones P (2014) Trends of temperature extremes in Saudi Arabia. Int J Climatol 34:808-826. doi:10.1002/joc.3722

4. Amarnath T, Mishra A (2017) Farmers need more help to adapt to climate change.Economic and Political Weekly52

5. Ashton PJ (2002) Avoiding conflicts over Africa's water resources.Ambio:236-242

6. Baldi P, Long AD (2001) A Bayesian framework for the analysis of microarray expression data: regularized t-test and statistical inferences of gene changes. Bioinformatics 17:509-519. doi:10.1093/bioinformatics/17.6.509

7. Boonwichai S, Shrestha S, Babel MS, Weesakul S, Datta A (2019) Evaluation of climate change impacts and adaptation strategies on rainfed rice production in Songkhram River Basin, Thailand. Sci Total Environ 652:189-201. doi:10.1016/j.scitotenv.2018.10.201 
8. Choy S, Wang C-S, Yeh T-K, Dawson J, Jia M, Kuleshov Y (2015) Precipitable water vapor estimates in the Australian region from ground-based GPS observations. Advances in Meteorology 2015. doi:10.1155/2015/956481

9. Efthymiadis D, Goodess C, Jones P (2011) Trends in Mediterranean gridded temperature extremes and large-scale circulation influences. Nat Hazards Earth Syst Sci 11:2199-2214. doi: 10.5194/nhess-11-2199-2011

10. Evans JP (2009) 21st century climate change in the Middle East. Clim Change 92:417-432

11. Gentle P, Maraseni TN (2012) Climate change, poverty and livelihoods: adaptation practices by rural mountain communities in Nepal. Environ Sci Policy 21:24-34. doi:10.1016/j.envsci.2012.03.007

12. Gleick PH (1994) Water, war \& peace in the Middle East. Environment: Sci policy sustainable Dev 36:6-42

13. Kuglitsch FG, Toreti A, Xoplaki E, Della-Marta PM, Zerefos CS, Türkeş M, Luterbacher J (2010) Heat wave changes in the eastern Mediterranean since 1960. Geophys Res Lett 37. doi:10.1029/2009GL041841

14. Lelieveld J, Hadjinicolaou P, Kostopoulou E, Chenoweth J, El Maayar M, Giannakopoulos C, Hannides C, Lange M, Tanarhte M, Tyrlis E (2012) Climate change and impacts in the Eastern Mediterranean and the Middle East. Clim Change 114:667-687

15. Maheras P, Flocas H, Tolika K, Anagnostopoulou C, Vafiadis M (2006) Circulation types and extreme temperature changes in Greece. Climate Res 30:161-174. doi:10.3354/cr030161

16. Maraseni TN, Deo RC, Qu J, Gentle P, Neupane PR (2018) An international comparison of rice consumption behaviours and greenhouse gas emissions from rice production. J Clean Prod 172:2288-2300 doi:10.1016/j.jclepro.2017.11.182

17. Marsaglia G, Tsang WW, Wang J (2003) Evaluating Kolmogorov's distribution. J Stat Softw 8:1-4. doi:10.18637/jss.v008.i18

18. Matouq M (2008) Predicting the impact of global warming on the Middle East region: Case Study on Hashemite Kingdom of Jordan using the application of geographical information system. J Appl Sci 8:462-470

19. Mitchell TR, Holtom BC, Lee TW, Sablynski CJ, Erez M (2001) Why people stay: Using job embeddedness to predict voluntary turnover. Acad Manag J 44:1102-1121. doi:10.5465/3069391

20. Nazemosadat M, Ghaedamini H (2010) On the relationships between the Madden-Julian oscillation and precipitation variability in southern Iran and the Arabian Peninsula: Atmospheric circulation analysis. J Clim 23:887-904 doi:10.1175/2009JCLI2141.1

21. Nazemosadat M, Ravan V, Kahya E, Ghaedamini H (2016) Projection of temperature and precipitation in southern Iran using ECHAM5 simulations. Iran J Sci Technol Trans A: Sci 40:3949 doi:10.1007/s40995-016-0009-8

22. Nazemosadat M, Samani N, Barry D, Molaii Niko M (2006) ENSO forcing on climate change in Iran: precipitation analysis. Iran J Sci Technol Trans B: Eng 30:555-565 
23. Noshadi M, Ahani H (2015) Focus on relative humidity trend in Iran and its relationship with temperature changes during 1960-2005. Environ Dev Sustain 17:1451-1469. doi:10.1007/s10668014-9615-9

24. Pal JS, Eltahir EA (2016) Future temperature in southwest Asia projected to exceed a threshold for human adaptability. Nat Clim Change 6:197-200. doi:10.1038/nclimate2833

25. Petkova EP, Ebi KL, Culp D, Redlener I (2015) Climate change and health on the US Gulf Coast: Public health adaptation is needed to address future risks. Int $\mathrm{J}$ Environ Res Public Health 12:9342-9356. doi:10.3390/ijerph120809342

26. Schaller N, Kay AL, Lamb R, Massey NR, Van Oldenborgh GJ, Otto FE, Sparrow SN, Vautard R, Yiou P, Ashpole I (2016) Human influence on climate in the 2014 southern England winter floods and their impacts. Nat Clim Change 6:627-634. doi:10.1038/nclimate2927

27. Shirvani A, Nazemosadat SJ, Kahya E (2015) Analyses of the Persian Gulf sea surface temperature: prediction and detection of climate change signals. Arab J Geosci 8:2121-2130. doi:10.1007/s12517-014-1278-1

28. Sowers J, Vengosh A, Weinthal E (2011) Climate change, water resources, and the politics of adaptation in the Middle East and North Africa. Clim Change 104:599-627. doi:10.1007/s10584010-9835-4

29. Tanarhte M, Hadjinicolaou P, Lelieveld J (2012) Intercomparison of temperature and precipitation data sets based on observations in the Mediterranean and the Middle East. J Geophys Research: Atmos 117. doi:10.1029/2011JD017293

30. Tanarhte M, Hadjinicolaou P, Lelieveld J (2015) Heat wave characteristics in the eastern Mediterranean and Middle East using extreme value theory. Climate Res 63:99-113. doi:10.3354/cr01285

31. Thompson WR, Zakhirova L (2021) Climate Change in the Middle East and North Africa: 15,000 Years of Crises, Setbacks, and Adaptation. Routledge. doi:10.4324/9781003158127

32. Trenberth KE, Fasullo JT (2009) Global warming due to increasing absorbed solar radiation.Geophysical Research Letters36

33. van Loon H, Shea DJ (2000) The global 11-year solar signal in July-August. Geophys Res Lett 27:2965-2968. doi:10.1029/2009GL037527

34. Wigley T, Santer B, Taylor K (2000) Correlation approaches to detection. Geophys Res Lett 27:29732976 doi:10.1029/2000GL011611

35. Wodon Q, Liverani A, Joseph G, Bougnoux N (2014) Climate change and migration: evidence from the Middle East and North Africa. World Bank Publications

36. Wyszyński P, Przybylak R (2014) Variability of humidity conditions in the Arctic during the first International Polar Year, 1882-83. Polar Res 33:23896. doi:10.3402/polar.v33.23896

37. Yoshida M, Ogawa R, Yoshida H, Maeshima A, Kanai Y, Kinoshita T, Hiraoka N, Sekine S (2015) TERT promoter mutations are frequent and show association with MED12 mutations in phyllodes tumors of the breast. Br J Cancer 113:1244-1248. doi:10.1038/bjc.2015.326 
38. Zhang X, Aguilar E, Sensoy S, Melkonyan H, Tagiyeva U, Ahmed N, Kutaladze N, Rahimzadeh F, Taghipour A, Hantosh T (2005) Trends in Middle East climate extreme indices from 1950 to 2003. J Geophys Research: Atmos 110. doi:10.1029/2005JD006181 doi:10.1029/2000GL011611

39. Wodon Q, Liverani A, Joseph G, Bougnoux N (2014) Climate change and migration: evidence from the Middle East and North Africa. World Bank Publications.

40. Wyszyński P, Przybylak R (2014) Variability of humidity conditions in the Arctic during the first International Polar Year, 1882-83. Polar Research 33:23896. doi:10.3402/polar.v33.23896

41. Yoshida M, Ogawa R, Yoshida H, Maeshima A, Kanai Y, Kinoshita T, Hiraoka N, Sekine S (2015) TERT promoter mutations are frequent and show association with MED12 mutations in phyllodes tumors of the breast. British journal of cancer 113:1244-1248. doi:10.1038/bjc.2015.326

42. Zhang X, Aguilar E, Sensoy S, Melkonyan H, Tagiyeva U, Ahmed N, Kutaladze N, Rahimzadeh F, Taghipour A, Hantosh T (2005) Trends in Middle East climate extreme indices from 1950 to 2003. Journal of Geophysical Research: Atmospheres 110. doi:10.1029/2005JD006181

\section{Tables}

Table 1 Differential val ues of AT, RH, U-wind and V-wind mean data between the periods of 1991-2020 and 1961-1990 for whole of the ME and the considered Ten sub-regions

\begin{tabular}{ccccccc}
\hline \multirow{2}{*}{ Area } & Latitude & Longitude & $\mathrm{AT}\left({ }^{\circ} \mathrm{C}\right)$ & $\mathrm{RH}(\%)$ & $\begin{array}{c}\text { U-wind } \\
\text { (m/s) }\end{array}$ & V-wind $(\mathrm{m} / \mathrm{s})$ \\
\cline { 4 - 8 } & & & \multicolumn{5}{c}{ Differential (D2-D1) } \\
\hline Middle-East & $10-45^{\circ} \mathrm{N}$ & $25-70^{\circ} \mathrm{E}$ & 0.83 & -1.93 & -0.15 & -0.01 \\
$\mathbf{A}$ & $30-35^{\circ} \mathrm{N}$ & $50-55^{\circ} \mathrm{E}$ & 0.93 & -2.08 & -0.53 & -0.67 \\
B & $35-42.5^{\circ} \mathrm{N}$ & $55-65^{\circ} \mathrm{E}$ & 0.98 & -2.58 & -0.46 & -0.03 \\
$\mathbf{C}$ & $12.5-17.5^{\circ} \mathrm{N}$ & $25-35^{\circ} \mathrm{E}$ & 1.72 & -10.06 & 0.15 & -0.54 \\
$\mathbf{D}$ & $25-30^{\circ} \mathrm{N}$ & $40-45^{\circ} \mathrm{E}$ & 1.03 & -1.28 & -0.38 & -0.57 \\
$\mathbf{E}$ & $17.5-22.5^{\circ} \mathrm{N}$ & $35-45^{\circ} \mathrm{E}$ & 1.16 & -2.34 & -0.38 & 0.07 \\
$\mathbf{F}$ & $35-40^{\circ} \mathrm{N}$ & $25-40^{\circ} \mathrm{E}$ & 1.02 & -2.00 & -0.51 & 0.30 \\
$\mathbf{G}$ & $35-40^{\circ} \mathrm{N}$ & $25-30^{\circ} \mathrm{E}$ & 0.94 & 0.05 & -0.37 & 0.69 \\
$\mathbf{H}$ & $20-22.5^{\circ} \mathrm{N}$ & $55-60^{\circ} \mathrm{E}$ & 0.09 & 3.62 & -0.66 & 0.42 \\
$\mathbf{I}$ & $27.5-32.5^{\circ} \mathrm{N}$ & $25-30^{\circ} \mathrm{E}$ & 0.91 & -0.88 & 0.19 & 0.26 \\
$\mathbf{J}$ & $32.5-37.5^{\circ} \mathrm{N}$ & $30-35^{\circ} \mathrm{E}$ & 0.84 & 0.01 & -0.51 & 0.26 \\
\hline
\end{tabular}

a- For AT and $\mathrm{RH}$, the positive (negative) values of differential data (D2 -D1) imply increase (decrease) during last 30 years as compared to the first 30 years period. Positive (negative) values of U-wind indicate strength (weakness) in the westerly winds and vice versa for the easterly airflows. Positive (negative) values of V-wind indicate strength (weakness) in the northward winds and vice-versa for the southward airflows 
b- As indicated in Figure 4, the sub-regions are denoted as A: Central part of Iran, B: the areas spread over the northeast of Iran, northwest of Afghanistan and southern parts of Turkmenistan, C: Sudan, D: north of Saudi Arabia, E: west of Saudi Arabia, the Red Sea and east of Sudan, F: Turkey, G: west of Turkey, H: north of Oman, I: north of Egypt, J: east of the Mediterranean Sea (Figure 4)

Table 2 The results of Kolmogorov-Smirnov test for assessing changes in AT, RH and VW between the periods of 1961-1990 and 1991-2020. * or ** indicates that the difference is significant at $90 \%$ or $95 \%$ level

\begin{tabular}{ccccccc}
\hline \multirow{2}{*}{ Area } & Latitude & Longitude & AT & RH & U-wind & V-wind \\
\hline Middle-East & $10-45^{\circ} \mathrm{N}$ & $25-70^{\circ} \mathrm{E}$ & $*$ & & & \\
A & $30-35^{\circ} \mathrm{N}$ & $50-55^{\circ} \mathrm{E}$ & & & & \\
B & $35-42.5^{\circ} \mathrm{N}$ & $55-65^{\circ} \mathrm{E}$ & $*$ & $*$ & \\
C & $12.5-17.5^{\circ} \mathrm{N}$ & $25-35^{\circ} \mathrm{E}$ & & $*$ & \\
D & $25-30^{\circ} \mathrm{N}$ & $40-45^{\circ} \mathrm{E}$ & & & \\
E & $17.5-22.5^{\circ} \mathrm{N}$ & $35-45^{\circ} \mathrm{E}$ & $*$ & & $*$ \\
F & $35-40^{\circ} \mathrm{N}$ & $25-40^{\circ} \mathrm{E}$ & & & \\
G & $35-40^{\circ} \mathrm{N}$ & $25-30^{\circ} \mathrm{E}$ & & & $*$ \\
H & $20-22.5^{\circ} \mathrm{N}$ & $55-60^{\circ} \mathrm{E}$ & & & $*$ \\
I & $27.5-32.5^{\circ} \mathrm{N}$ & $25-30^{\circ} \mathrm{E}$ & & & $*$ \\
J & $32.5-37.5^{\circ} \mathrm{N}$ & $30-35^{\circ} \mathrm{E}$ & $*$ & & $*$ \\
\hline
\end{tabular}

The sub-regions are A: Central part of Iran, B: Northeast of Iran, Northwest of Afghanistan and Turkmenistan, C: Sudan, D: North of Saudi Arabia, E: West of Saudi Arabia, F: Turkey, G: West of Turkey, H: North of Oman, I: North of Egypt, J: East of Mediterranean Sea 
Table 3 Similar to Table 1 except between the 1961-1970 and 2011-2020

\begin{tabular}{crrrrrr}
\hline \multirow{2}{*}{ Area } & Latitude & Longitude & \multicolumn{5}{c}{ P-value } \\
\cline { 5 - 7 } Middle-East & $10-45^{\circ} \mathrm{N}$ & $25-70^{\circ} \mathrm{E}$ & $* *$ & $*$ & $*$ & \\
A & $30-35^{\circ} \mathrm{N}$ & $50-55^{\circ} \mathrm{E}$ & & & $* *$ & \\
B & $35-42.5^{\circ} \mathrm{N}$ & $55-65^{\circ} \mathrm{E}$ & $* *$ & $* *$ & & \\
C & $12.5-17.5^{\circ} \mathrm{N}$ & $25-35^{\circ} \mathrm{E}$ & $*$ & $* *$ & $*$ & $*$ \\
D & $25-30^{\circ} \mathrm{N}$ & $40-45^{\circ} \mathrm{E}$ & $*$ & $*$ & & \\
E & $17.5-22.5^{\circ} \mathrm{N}$ & $35-45^{\circ} \mathrm{E}$ & $* *$ & & $* *$ & \\
F & $35-40^{\circ} \mathrm{N}$ & $25-40^{\circ} \mathrm{E}$ & $*$ & & $*$ & $* *$ \\
G & $35-40^{\circ} \mathrm{N}$ & $25-30^{\circ} \mathrm{E}$ & $* *$ & & & $* *$ \\
H & $20-22.5^{\circ} \mathrm{N}$ & $55-60^{\circ} \mathrm{E}$ & & & $*$ & $*$ \\
I & $27.5-32.5^{\circ} \mathrm{N}$ & $25-30^{\circ} \mathrm{E}$ & & & $*$ & $*$ \\
J & $32.5-37.5^{\circ} \mathrm{N}$ & $30-35^{\circ} \mathrm{E}$ & $* *$ & & $*$ & $*$ \\
\hline
\end{tabular}

* or ** indicates that the difference is significant at the 0.10 or 0.05 levels, respectively

Table 4 Similar to Table 1 except between the 1961-1965 and 2016-2020

\begin{tabular}{ccccccc}
\hline \multirow{2}{*}{ Area } & \multirow{2}{*}{ Latitude } & Longitude & \multicolumn{5}{c}{ P-value } \\
\cline { 5 - 7 } Middle-East & $10-45^{\circ} \mathrm{N}$ & $25-70^{\circ} \mathrm{E}$ & $* *$ & $*$ & $* *$ & \\
A & $30-35^{\circ} \mathrm{N}$ & $50-55^{\circ} \mathrm{E}$ & & & $* *$ & \\
B & $35-42.5^{\circ} \mathrm{N}$ & $55-65^{\circ} \mathrm{E}$ & $* *$ & $* *$ & & \\
C & $12.5-17.5^{\circ} \mathrm{N}$ & $25-35^{\circ} \mathrm{E}$ & $* *$ & $* *$ & $* *$ & $* *$ \\
D & $25-30^{\circ} \mathrm{N}$ & $40-45^{\circ} \mathrm{E}$ & & $*$ & & $*$ \\
E & $17.5-22.5^{\circ} \mathrm{N}$ & $35-45^{\circ} \mathrm{E}$ & $* *$ & $*$ & $* *$ & $*$ \\
F & $35-40 \mathrm{~N}$ & $25-40 \mathrm{E}$ & $* *$ & $* *$ & & $* *$ \\
G & $35-40 \mathrm{~N}$ & $25-30 \mathrm{E}$ & $* *$ & & & $* *$ \\
H & $20-22.5 \mathrm{~N}$ & $55-60 \mathrm{E}$ & & & $* *$ & $*$ \\
I & $27.5-32.5 \mathrm{~N}$ & $25-30 \mathrm{E}$ & $*$ & & $* *$ & $*$ \\
J & $32.5-37.5^{\circ} \mathrm{N}$ & $30-35^{\circ} \mathrm{E}$ & $* *$ & & & $* *$ \\
\hline
\end{tabular}

* or ** indicates that the difference is significant at the 0.10 or 0.05 levels, respectively 


\section{Figures}

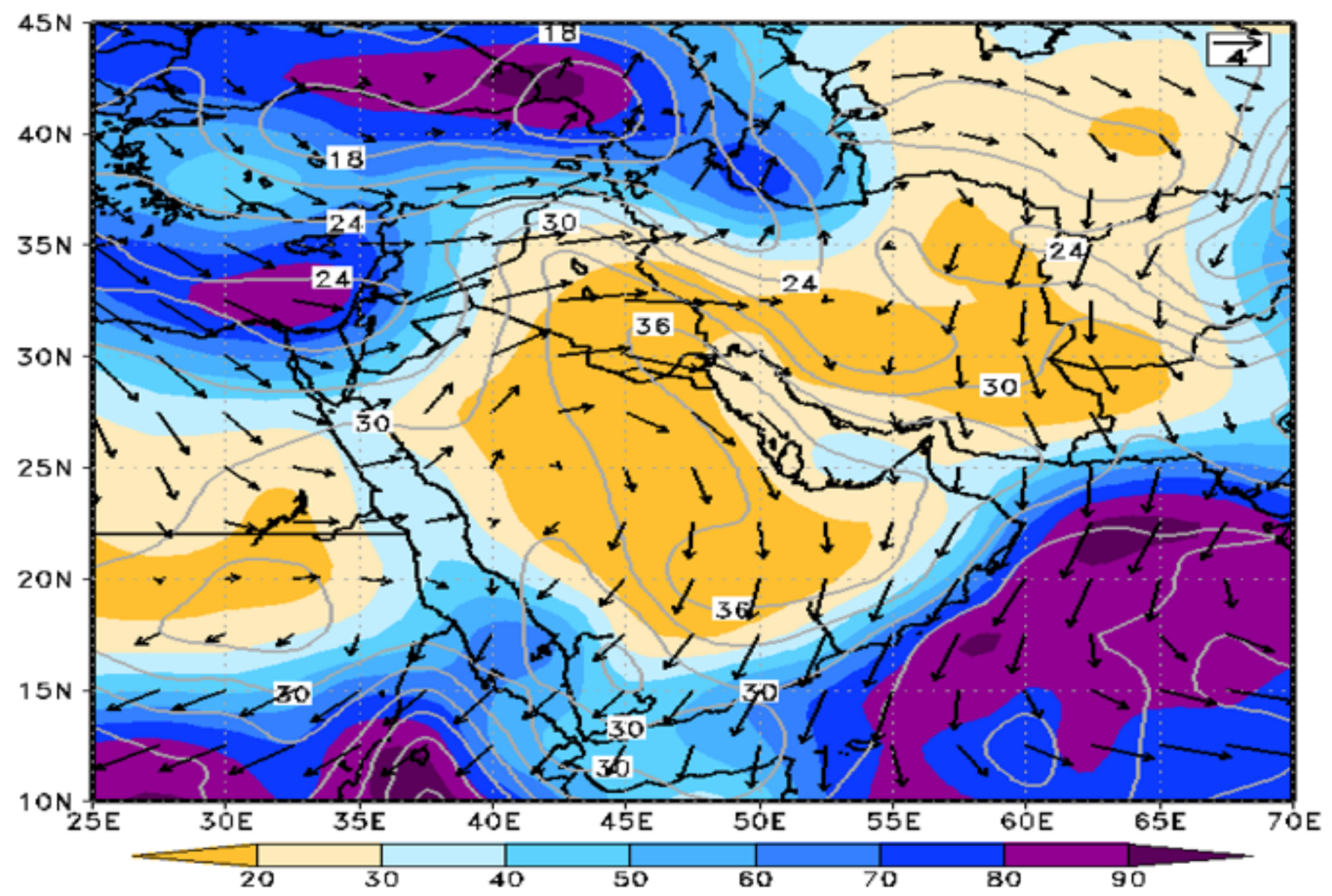

Figure 1

The summertime (Jun-Sep) values of air temperature (AT), relative humidity $(\mathrm{RH})$ and vector wind over the period of 1961 to 1990 . The contour lines, shading and vectors show AT in degree Centigrade, RH in percentage and VW in $\mathrm{m} / \mathrm{s}$ 


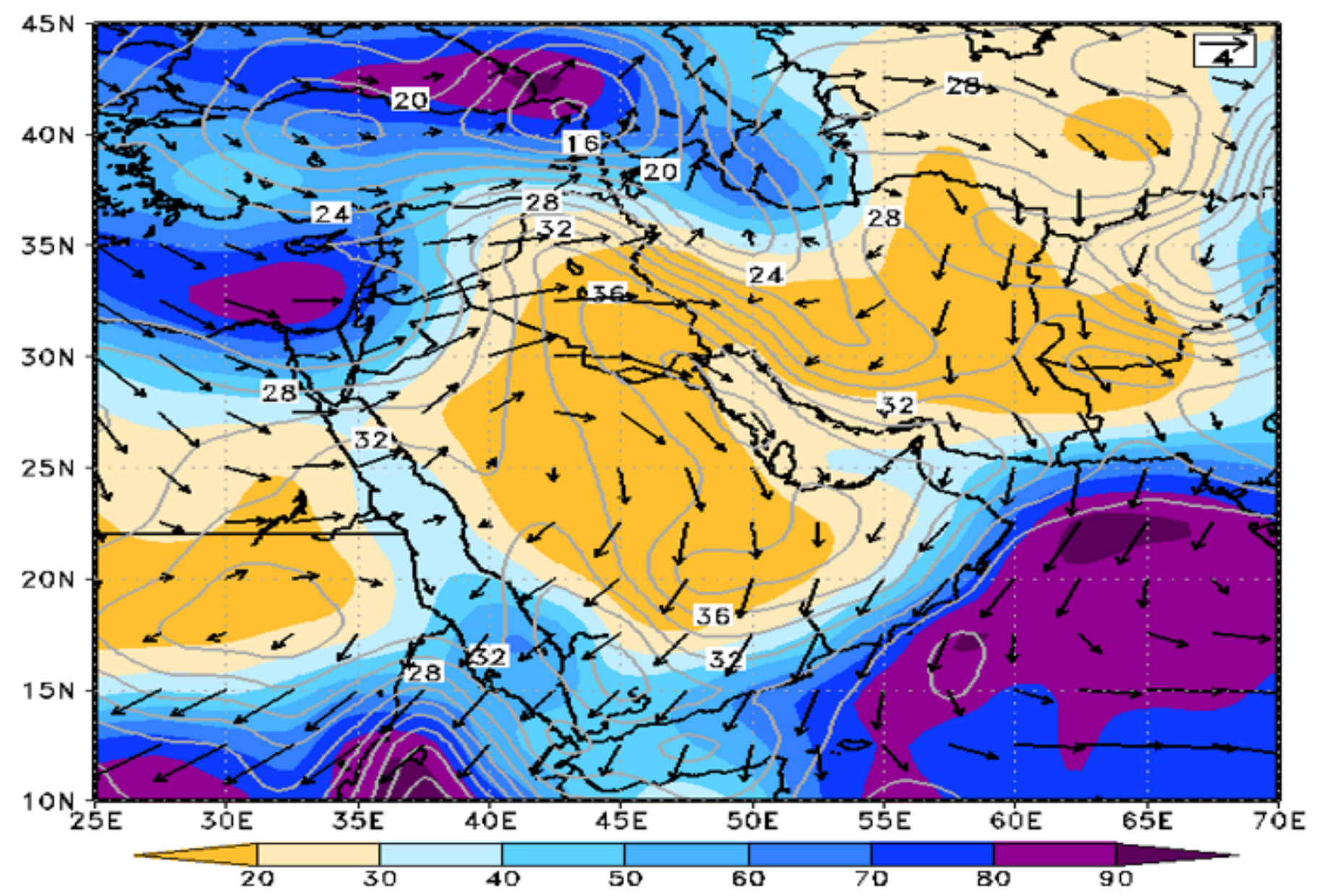

Figure 2

Similar to Figure 1 except for the period of 1991 to 2020 


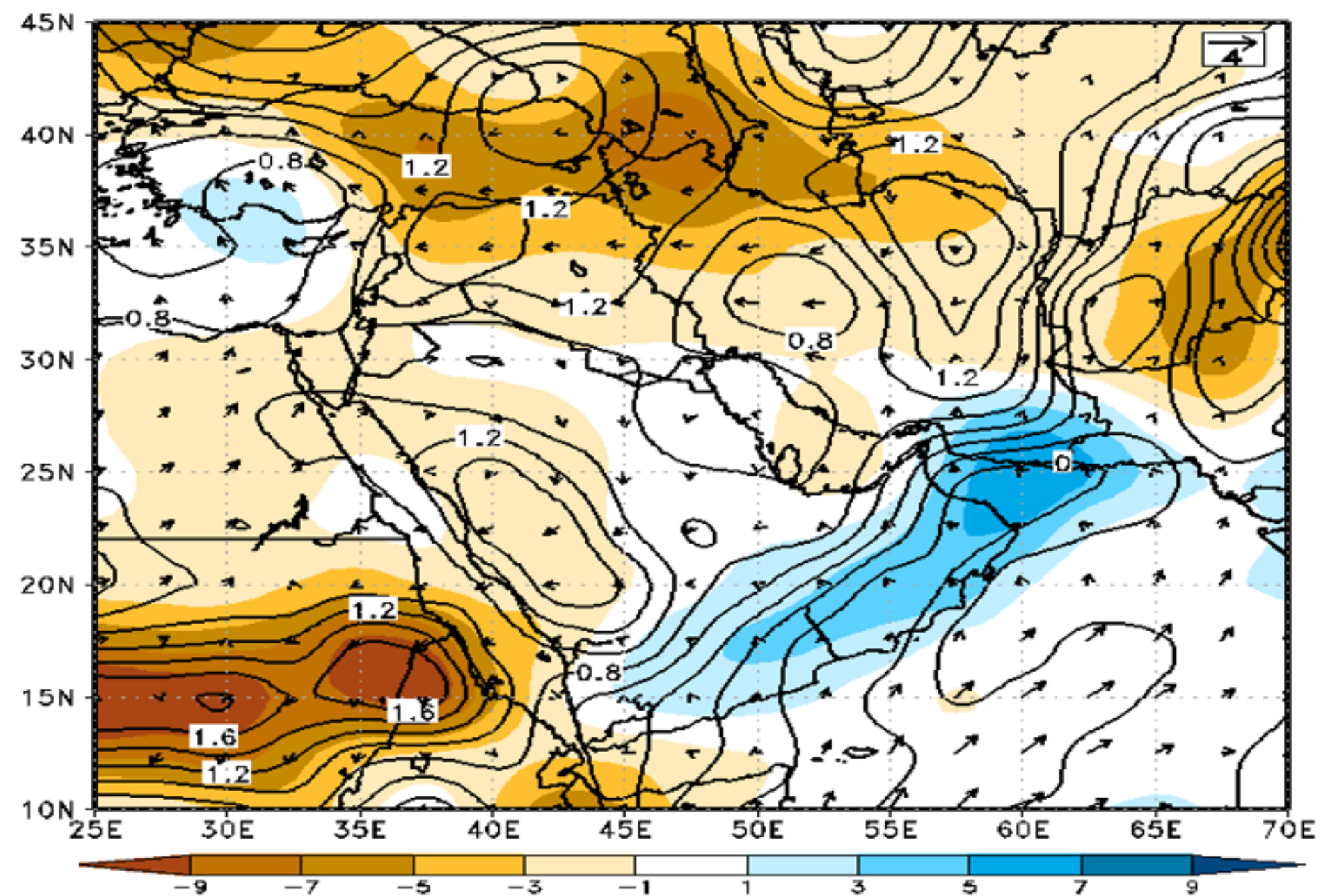

Figure 3

Differential values between Figure 1 and Figure 2. The contour lines, shading and vectors show AT in degree Centigrade, $\mathrm{RH}$ in percentage and VW in $\mathrm{m} / \mathrm{s}$ 


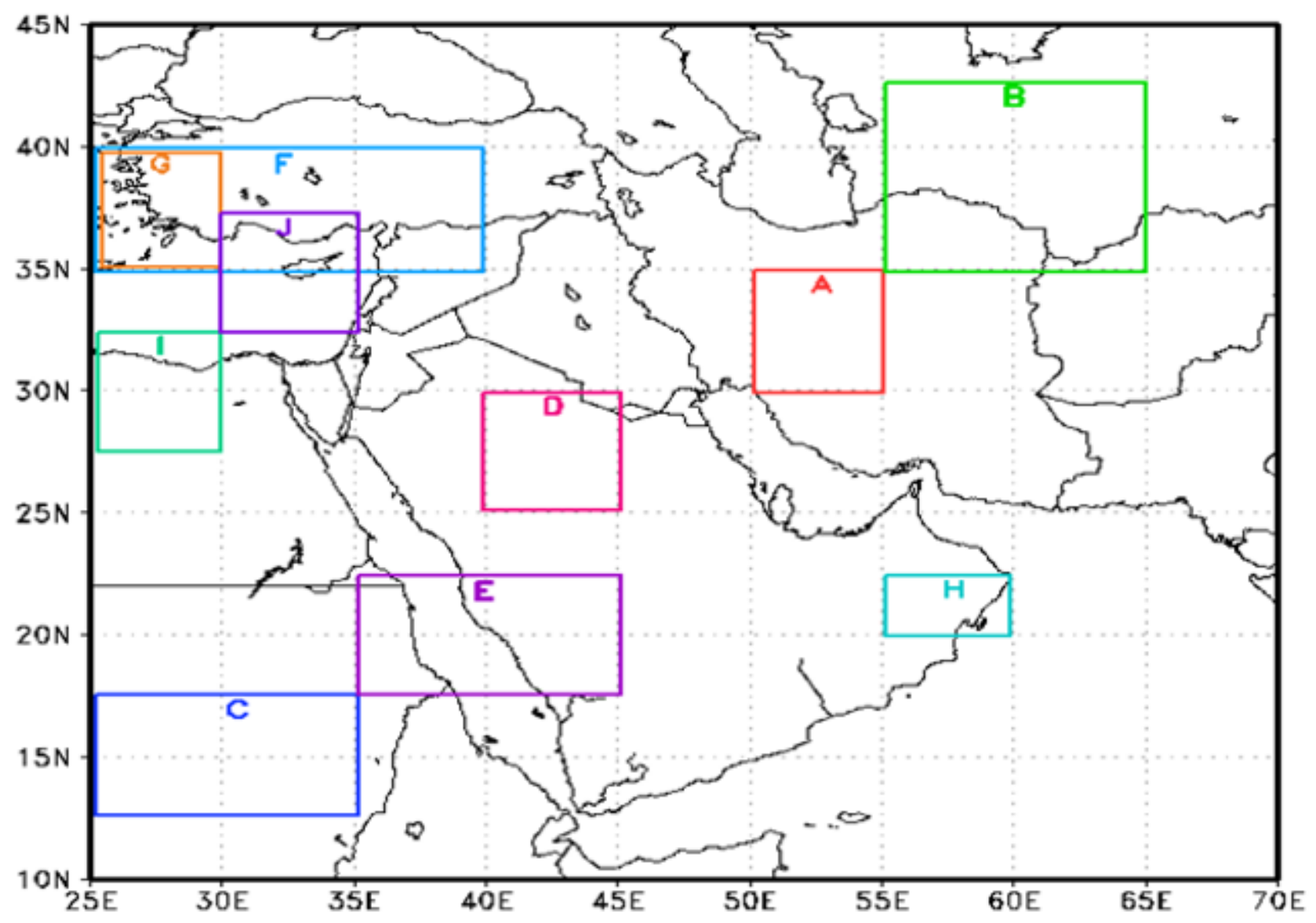

Figure 4

The geographical domain of ten sub-regions for which climate changed are examined. The change is firstly detected over the whole part of the ME and then for these sub-regions. The geographical boundaries of the sub-regions are A: Central part of Iran, B: Northeast of Iran, Northwest of Afghanistan and Turkmenistan, C: Sudan, D: North of Saudi Arabia, E: West of Saudi Arabia, F: Turkey, G: West of Turkey, H: North of Oman, I: North of Egypt, J: East of Mediterranean Sea 


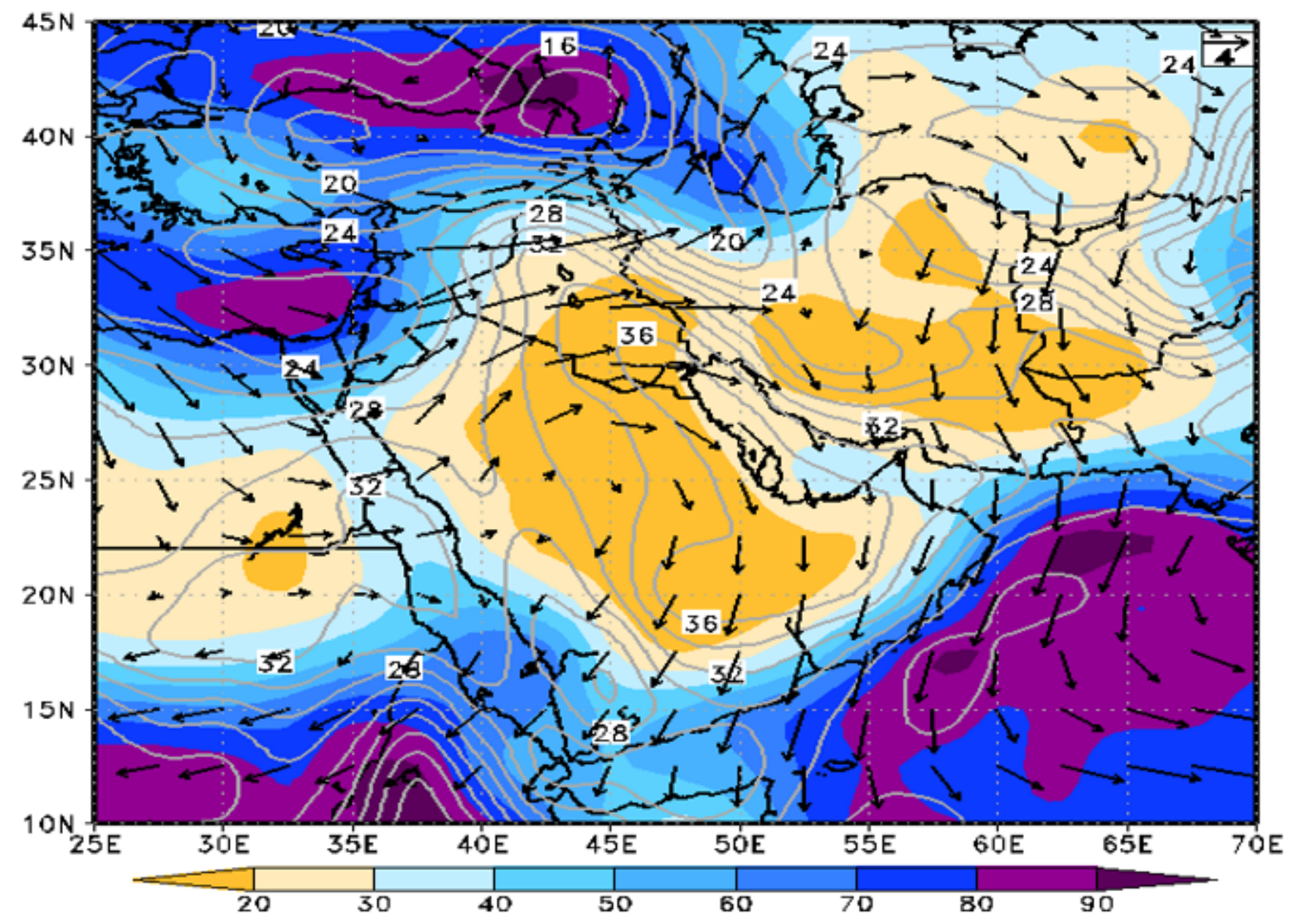

Figure 5

Similar to Figure 1 except for 1961 to 1970 


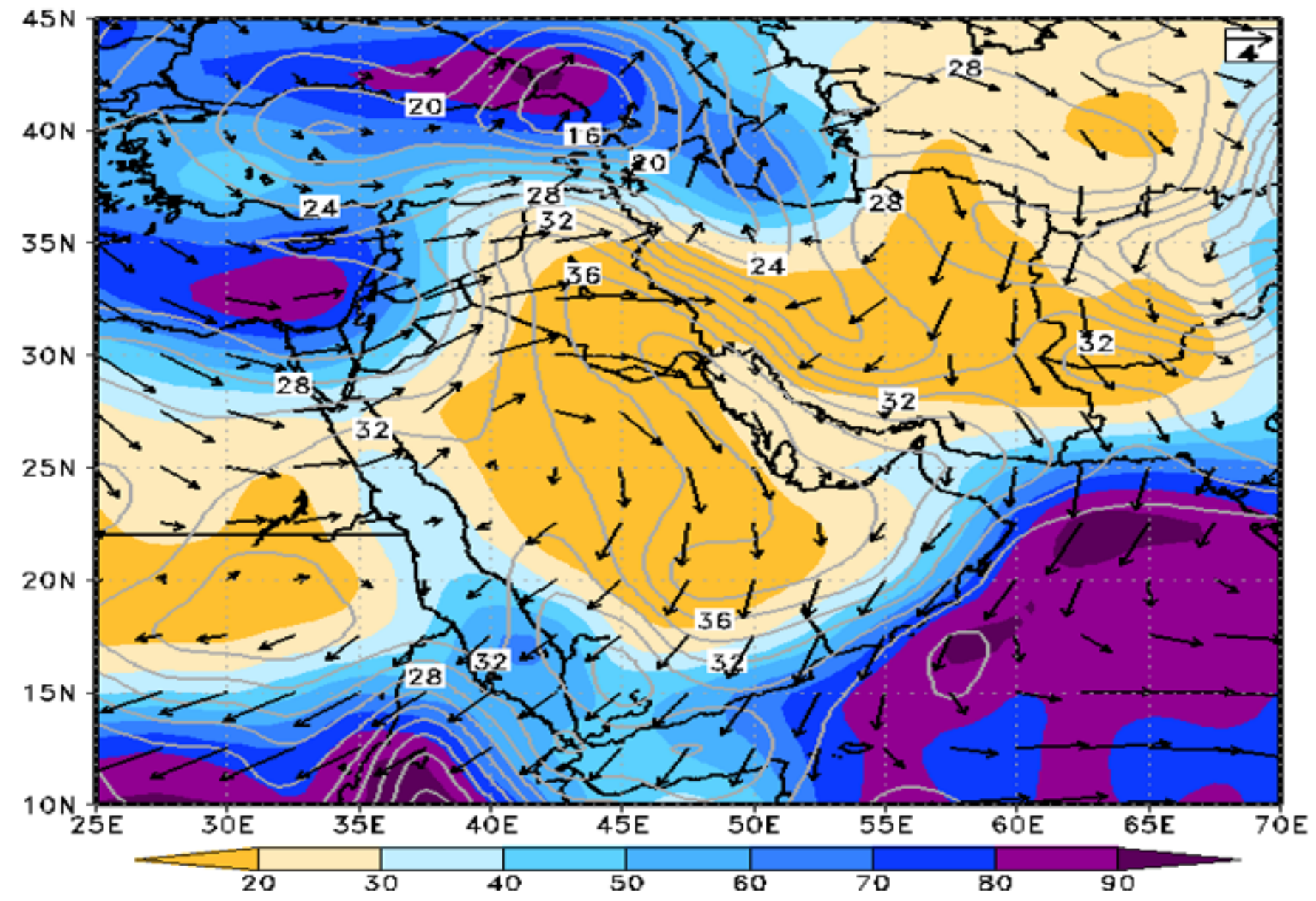

Figure 6

Similar to Figure 4 except for the period of 2011 to 2020 


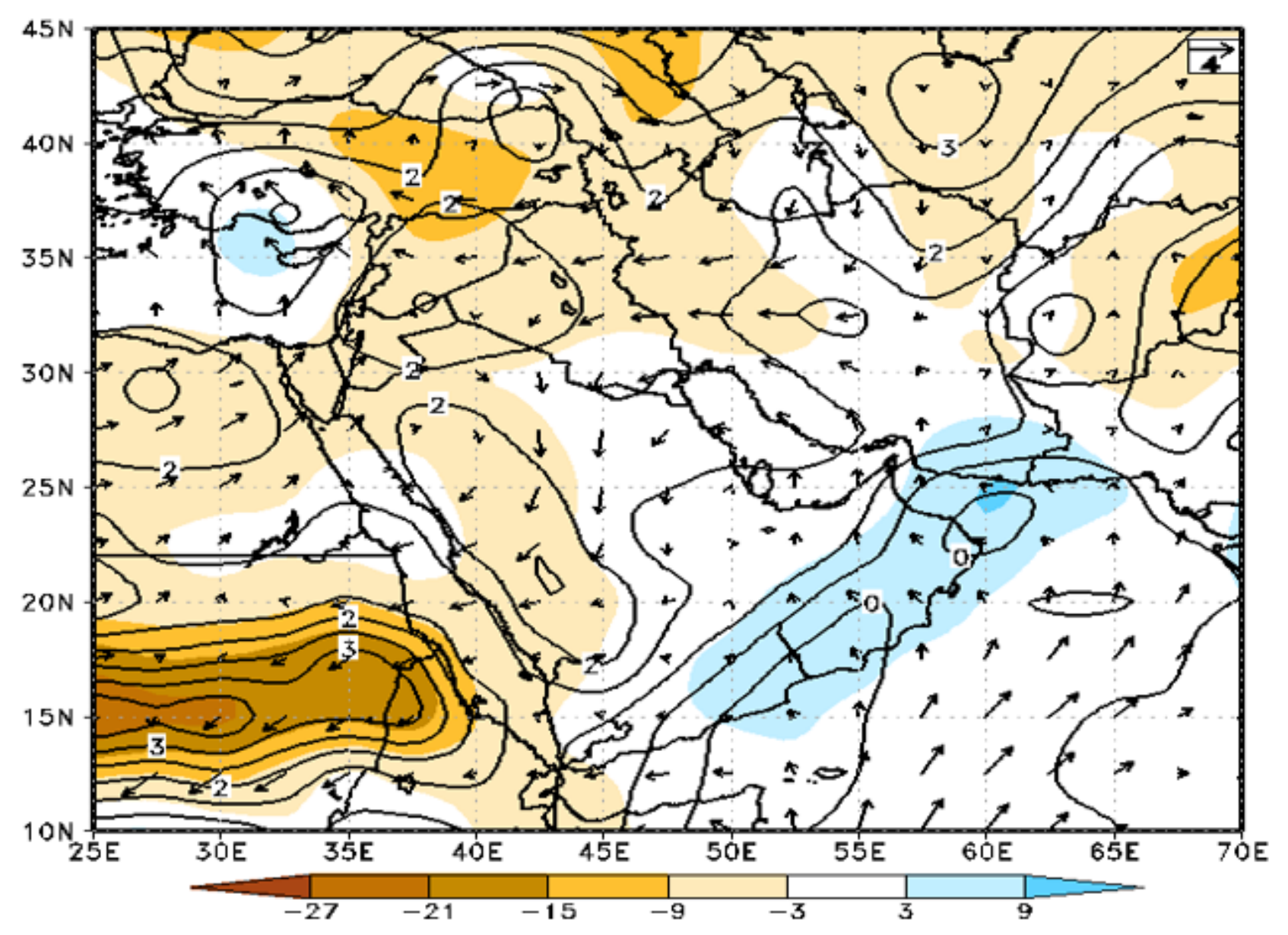

Figure 7

Differential values between Figure 5 and Figure 6 (2011-2020 - 1961-1970). The contour lines, shading and vectors show AT in degree Centigrade, $\mathrm{RH}$ in percentage and VW in $\mathrm{m} / \mathrm{s}$ 


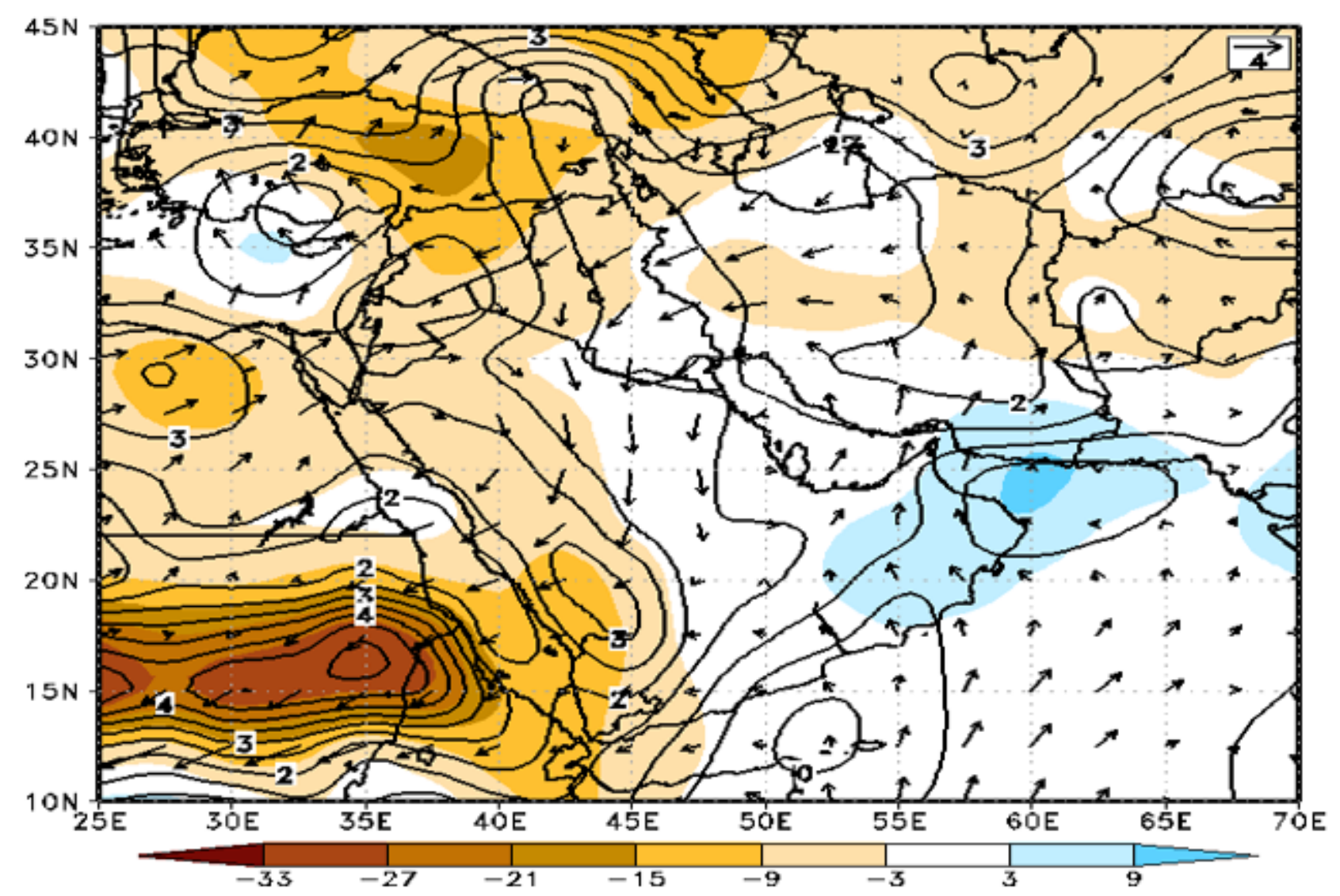

Figure 8

Differential values between Figure 1 and Figure 2 except for (2016-2020 - 1961-1965). The contour lines, shading and vectors show AT in degree Centigrade, $\mathrm{RH}$ in percentage and VW in $\mathrm{m} / \mathrm{s}$ 